\title{
ANALISIS MIKROBIOLOGI DAN MUTU GIZI KEFIR SUSU KAMBING BERDASARKAN WAKTU FORTIFIKASI VITAMIN $B_{12}$
}

\author{
Gita Riski Rahayu, Reza Achmad Maulana, Fitriyono Ayustaningwarno, Binar Panunggal, Gemala Anjani* \\ Departemen Ilmu Gizi, Fakultas Kedokteran, Universitas Diponegoro. J1. Prof. Sudarto SH, Tembalang, Semarang, Jawa Tengah 50275, Indonesia \\ *Penulis Penanggungjawab: E-mail: gemaanjani@gmail.com
}

\begin{abstract}
Background: Goat milk has low of vitamin $B_{12}$ content compared to cow's milk which had 0.065 mg/l00 gr. One way to increase vitamin $B_{12}$ content in goat milk by making product of fortified kefir of vitamin $B_{12}$. The addition of vitamin $B_{12}$ in kefir is based on the curve of bacterial growth in kefir.

Objectives: To analyze microbiology characteristics and nutrition quality of goat milk kefir based on various fortification time of vitamin $B_{12}$

Methods: This study was a true experiment with completely randomized single factor design. Samples were split into 6 groups, namely fortified on the 0, 6th, 12th, 18th, or 24th hour of fermentation and a control group. Vitamin $B_{12}$ and protein content were determined using spectrophotometry. Fiber was measured with gravimetry, total fat by babcock method, total lactic bacteria was counted using total plate count, viscosity was measured with ostwald viscometer, and pH was determined through $\mathrm{pH}$ meter.

Results: There was no effect of fortification time on vitamin $B_{12}$ content $(p=0.169)$, protein content $(p=0.343)$, BAL total $(p=0.442)$. The highest vitamin $B_{12}$ concentration was observed in the kefir fortified at the 6th hour, highest protein content found at fortification at the 6th and 12th hour. On the other hand, there was an affect of fortification time on fiber content $(p=0.028)$, fat content $(p=0.000)$, viscosity $(p=0.007), p H p H(p=0.045)$. The highest fiber content was observed in kefir fortified at the 24th hour, and the highest fat content, viscosity, $\mathrm{pH}$ was observed in kefir fortified at the 18th hour.

Conclusion: Vitamin $B_{12}$ fortification effect fiber, fat content, viscosity, and pH of goat milk kefir. Vitamin $B_{12}$ content, protein, and total lactic acid bacteria does not effected by vitamin $B_{12}$ fortification time.
\end{abstract}

Keywords: Goat milk kefir; vitamin $B_{12}$; microbiology characteristics; nutrition quality; fortification time

\begin{abstract}
ABSTRAK
Latar belakang: Susu kambing mempunyai kandungan vitamin $B_{12}$ rendah dibandingkan susu sapi yaitu 0,065 mg/100 gr. Salah satu cara untuk meningkatkan kandungan vitamin $B_{12}$ pada susu kambing dengan membuat produk olahan kefir yang difortifikasi vitamin $B_{12}$. Penambahan vitamin $B_{12}$ pada kefir didasarkan pada kurfa pertumbuhan bakteri pada kefir.

Tujuan: Menganalisis karakteristik mikrobiologi dan mutu gizi kefir susu kambing pada berbagai waktu fortifikasi vitamin $B_{12}$

Metode: Penelitian ini merupakan true experimental dengan rancangan acak lengkap satu faktor, yaitu dengan fortifikasi vitamin $B_{12}$ pada jam ke-0,6,12,18,34 fermentasi kefir susu kambing. Kandungan vitamin $B_{12}$ dan protein diuji menggunakan metode spektrofotometri, serat diuji menggunakan metode grafimetri, lemak diuji menggunakan metode babcock, total bakteri asam laktat (BAL) dihitung menggunakan metode Total Plate Count, viskositas diuji menggunakan metode viskometer ostwald, dan derajat keasaman $(\mathrm{pH})$ di ukur menggunakan pH meter.

Hasil: Waktu fortifikasi vitamin $B_{12}$ tidak berdampak signifikan pada kandungan vitamin $B_{12}(p=0,169)$, kandungan protein $(p=0,343)$, total BAL $(p=0,442)$. Kandungan vitamin $B_{12}$ dan total BAL tertinggi pada waktu fortifikasi jam ke6 , kandungan protein tertinggi pada waktu fortifikasi jam ke-6 dan jam ke-12. Selain itu terdapat pengaruh waktu fortifikasi vitamin $B_{12}$ terhadap kandungan serat $(p=0,028)$, kandungan lemak $(p=0,000)$, viskositas $(p=0,007)$, pH $(p=0,045)$. Kandungan serat tertinggi pada waktu fortifikasi jam ke-24, dan kandungan lemak, viskositas, pH tertinggi pada faktu fortifikasi jam ke-18

Simpulan: Waktu fortifikasi vitamin $B_{12}$ mempengaruhi kandungan serat, lemak, viskositas, dan pH pada kefir susu kambing. Kandungan vitamin $B_{12}$, protein, dan total bakteri asam laktat tidak dipengaruhi oleh waktu fortifikasi vitamin $B_{12}$.
\end{abstract}

Kata Kunci : kefir susu kambing, vitamin $B_{12}$, karakteristik mikrobiologi, mutu gizi, waktu fortifikasi

\section{PENDAHULUAN}

Resistensi insulin terjadi karena disfungsi dari sel $\beta$-pankreas. Sel-sel dalam pankreas gagal untuk mengontrol kadar glukosa darah akibat gangguan pelepasan insulin. Disfungsi sel $\beta$-pankreas penyebabkan terjadinya diabetes melitus tipe $2 .{ }^{1}$ 
Diabetes tipe 2 merupakan salah satu penyakit radikal bebas yang dapat meningkatkan komplikasi dengan peningkatan lipid peroxide. Pada diabetes melitus tipe 2, stres oksidatif meningkat karena terjadi peningkatan produksi oxygen-free radicals dan sistem pertahanan antioksidan yang bekerja tidak efisien. Peningkatan free-radikal mengakibatkan peroksidasi lipid yang memicu terjadinya atherosklerosis dan komplikasi pada diabetes tipe 2. Sebuah penelitian menunjukkan bahwa peningkatan konsentrasi homosistein dan stres oksidatif berhubungan dengan diabates melitus tipe 2. Kondisi stres oksidatif pada diabetes dapat menyebabkan resistensi insulun dan menyebabkan pengurangan penyerapan glukosa di jaringan perifer. $^{2}$

Kefir merupakan minuman dengan konsistensi kental, dengan keasaman tinggi dan terdapat berbagai jumlah alkohol serta karbondioksida. Pada kefir akan menghasilkan bakteri seperti Lactococci $s p$, Lactobacilli $s p$, bakteri asam asetat dan ragi. ${ }^{3}$ Kefir berbeda dengan susu fermentasi lainnya karena pada kefir terdapat butiran kecil-kecil pada susu setelah dilakukan fermentasi dan juga pada kefir menghasilkan probiotik alami serta prebiotik. Konsumsi probiotik dapat menurunkan serum glukosa dan glukosa toleran pada diabetes. ${ }^{2}$ Probiotik dapat memperbaiki resistensi insulin dengan mengurangi respon inflamasi pada diabetes. Kefir yang dibuat dari susu kambing memiliki kandungan probiotik dan senyawa bioaktif seperti antioksidan, dan zat fenolik lebih tinggi dibandingkan dengan kefir yang berbahan dasar dari susu sapi. ${ }^{3}$

Susu kambing merupakan salah satu produk hewani yang apabila dikonsumsi tidak menimbulkan efek negatif bagi orang-orang yang menderita alergi susu sapi. ${ }^{4}$ Protein dan asam amino yang terdapat pada susu kambing lebih mudah diserap dan lebih efisien dari susu sapi. Susu kambing memiliki kandungan lemak tak jenuh tunggal (MUFA), asam lemak jenuh ganda (PUFA) dan medium chain triglycerides (MCT) lebih tinggi dibandingkan susu sapi, yang bermanfaat untuk kesehatan terutama untuk penderita kardiovaskuler.

Mengkonsumsi susu kambing dapat menurunkan kadar kolesterol total dan menurunkan LDLkarena kandungan medium chain triglycerides (MCT) lebih tinggi dari pada susu sapi, sehingga dapat menurunkan sintesis kolesterol endogen. ${ }^{5}$ Susu kambing memiliki kandungan vitamin B12 yang rendah dibandingkan susu sapi yaitu sekitar 0.065 $\mathrm{mg} / 100$ gr sedangkan pada susu sapi sebanyak 0,357 $\mathrm{mg} / 100$ gr, sehingga perlu dilakukan fortifikasi vitamin B 12 pada pembuatan kefir susu kambing. ${ }^{6}$ Selain itu susu kambing juga diketahui memiliki kandungan antioksidan yang tinggi karena kandungan komponen peptida yang dihubungkan dengan penurunan resiko penyakit degeneratif. ${ }^{7}$

Kefir memiliki kandungan mikronutrien dan makronutrien yang berperan penting dalam sistem homeostasis tubuh. Beberapa penelitian menghubungkan konsumsi kefir dengan penurunan risiko diabetes mellitus melalui perannya meningkatkan uptake glukosa oleh insulin, peningkatan fungsi sel beta, dan dibuktikan dengan penurunan glukosa darah dan level HbA1C pada pasien diabetes mellitus tipe 2.,8,9

Fortifikasi merupakan penambahan zat gizi dalam jumlah yang cukup besar pada suatu produk pangan sehingga produk tersebut dapat berfungsi sebagai sumber utama gizi yang ditambah terutama bagi masyarakat target. Tujuan utama fortifikasi ialah meningkatkan tingkat konsumsi dari zat gizi yang ditambahkan untuk meningkatkan status gizi populasi. ${ }^{10}$ Fortifikasi vitamin B12 dilakukan pada jam ke-0,6,12,18,24, hal ini dilakukan berdasarkan kurva pertumbuhan bakteri pada kefir dimana pada jam ke 24 pertumbuhan bakteri pada kefir menunjukan hasil yang paling optimal. ${ }^{11}$

Defisiensi vitamin $\mathrm{B}_{12}$ dapat mengakibatkan anemia, penyakit neurologis, cacat lahir, gangguan perkembangan saraf, dan hyperhomocysteinemia. Dalam pemenuhan kebutuhan sehari-hari asupan asam folat dan vitamin $B_{12}$ harus cukup untuk mendukung beberapa jalur metabolisme, terutama siklus metionin. Rendahnya asam folat dan vitamin $\mathrm{B}_{12}$ akan berdampak pada metionin sintase yang menjadi hypoactive. ${ }^{12}$ Jika metionin menjadi hypoactive sehingga akan terjadi stress oksidative dan akan memicu terjadinya resistensi insulin. ${ }^{13,14}$

Defisiensi vitamin $\mathrm{B}_{12}$ pada orang dewasa tejadi karena kurangnya asupan vitamin $\mathrm{B}_{12}$ dalam makanan dan terjadi malabsorpsi usus. Malabsorbsi vitamin $B_{12}$ juga berhubungan dengan terapi metformin (insulin sensitizer yang digunakan untuk pengobatan diabetes tipe 2) dan peningkatan resistensi insulin pada remaja obesitas. Obesitas menjadi salah satu faktor terjadinya defisiensi vitamin $\mathrm{B}_{12}$, dan orang obesitas memiliki faktor risiko terjadinya diabetes tipe 2 yang akan menyebabkan resistensi insulin.

Fortifikasi vitamin $B_{12}$ dilakukan untuk melihat karakteristik fisik dan mutu gizi pada kefir susu kambing. Kefir susu kambing dengan fortifikasi vitamin $\mathrm{B}_{12}$ yang diharapkan memiliki karakteristik fisik dan mutu gizi yang baik dan dapat menjadi alternatif pangan sebagai pencegah defisiensi vitamin $\mathrm{B}_{12}$ pada penderita resistensi insulin. 


\section{METODE}

Penelitian dilakukan di Laboratorium Terpadu Universitas Diponegoro untuk pembuatan, uji protein, lemak, serat, viskositas, vitamin $\mathrm{B}_{12}$, derajat keasaman $(\mathrm{pH})$, dan total bakteri asam laktat kefir susu kambing fortifikasi vitamin $\mathrm{B}_{12}$. Susu kambing segar dan bibit kefir berasal dari "Omah Kefir" di Ungaran.

Penelitian ini merupakan penelitian dengan rancangan acak lengkap satu faktor, yaitu fortifikasi vitamin $B_{12}$ pada jam ke 0 , jam ke 6 , jam ke 12 , jam ke 18, jam ke 24 pada kefir susu kambing. Penentuan jumlah vitamin $\mathrm{B}_{12}$ didapatkan dari hasil penelitian pendahuluan. Analisis protein, lemak, serat, viskositas, vitamin $\mathrm{B}_{12}$, derajat keasaman $(\mathrm{pH})$, dan total bakteri asam laktat dilakukan dengan 3 ulangan.

Pembuatan kefir susu kambing dengan fortifikasi vitamin $\mathrm{B}_{12}$ diawali dengan pasteurisasi susu pada suhu $85^{\circ} \mathrm{C}$ selama 30 menit kemudian didinginkan hingga suhu $28^{\circ} \mathrm{C}$. Selanjutnya susu di inokulasi dengan bibit kefir sebanyak 5\% dan dibagi menjadi 6 kelompok, yaitu 1 kelompok kontrol dan 5 kelompok perlakuan, setiap kelompok terdiri dari 5 sampel. Inkubasi kefir susu kambing pada suhu $23^{\circ} \mathrm{C}$ selama 24 jam. Fortifikasi vitamin $\mathrm{B}_{12}$ sebanyak $20 \mu \mathrm{g} / 100 \mathrm{ml}$ kefir susu kambing kelompok perlakuan pada waktu fermentasi ke 0 , jam ke 6, jam ke 12, jam ke 18, jam ke 24. Setelah waktu fermentasi selesai lakukan penyaringan agar bibit kefir dapat terpisah.

Uji protein menggunakan metode Bradford, uji lemak menggunakan metode Babcock, uji protein dan vitamin $\mathrm{B}_{12}$ menggunakan metode spektrofotometri, uji $\mathrm{pH}$ menggunakan $\mathrm{pH}$ meter, uji serat menggunakan metode Gravimetri, uji viskositas menggunakan viscometer, uji total bakteri asam laktat menggunakan metode Total Plate Count (TPC).

Seluruh data yang telah dikumpulkan diolah menggunakan software statistik. Data diuji normalitasnya menggunakan uji Saphiro-Wilk. Data berdistribusi normal dianalisis dengan uji One Way Anova dengan uji lanjut Tukey. Data yang berdistribusi tidak normal analisi dengan uji Kruskal-Wallis dengan uji lanjut Man-Whitney.

\section{HASIL \\ Protein}

Hasil analisis protein pada kefir susu kambing fortifikasi vitamin $\mathrm{B}_{12}$ didapat $p=0,343$, maka tidak ada pengaruh waktu fortifikasi vitamin $\mathrm{B}_{12}$ terhadap kandungan protein kefir susu kambing.
Tabel 1. Analisis Protein

\begin{tabular}{ll}
\hline Waktu Fortifikasi & Kandungan protein $(\mathbf{g r} / \mathbf{1 0 0 m l})$ \\
\hline Kontrol & $0,62 \pm 0,071$ \\
Jam ke 0 & $0,67 \pm 0,15$ \\
Jam ke 6 & $0,77 \pm 0,05$ \\
Jam ke 12 & $0,77 \pm 0,80$ \\
Jam ke 18 & $0,72 \pm 0,89$ \\
Jam ke 24 & $0,69 \pm 0,32$ \\
\hline & $p=0,343$ \\
\hline
\end{tabular}

\section{Serat}

Hasil analisis serat pada kefir susu kambing dengan fortifikasi vitamin B12 didapat $p=0,028$, maka terdapat pengaruh waktu fortifikasi vitamin $\mathrm{B}_{12}$ terhadap kandungan serat kefir susu kambing. Dari hasil uji lanjut didapatkan perbedaan kandungan serat antara kelompok kontrol dengan semua waktu fortifikasi, waktu fortitifikasi jam ke 12 dengan waktu fortifikasi jam ke 18 dan 24, serta waktu fortifikasi jam ke 18 dengan waktu fortifikasi jam ke 24.

Tabel 2. Analisis Serat

\begin{tabular}{ll}
\hline Waktu Fortifikasi & Kandungan Serat $(\mathbf{g r} / \mathbf{1 0 0 m l})^{*}$ \\
\hline Kontrol & $22,5^{\text {a }}$ \\
Jam ke 0 & $6,9^{\text {bcd }}$ \\
Jam ke 6 & $6,5^{\text {bcd }}$ \\
Jam ke 12 & $9^{\text {b }}$ \\
Jam ke 18 & $3^{\text {c }}$ \\
Jam ke 24 & $12,9^{\text {d }}$ \\
\hline & $p=0,028$ \\
\hline
\end{tabular}

*Data disajikan dalam Median; Keterangan : angka yang diikuti huruf super script berdeda (a,b,c,d) menunjukkan beda nyata

\section{Lemak}

Hasil analisis lemak pada kefir susu kambing dengan fortifikasi vitamin B12 didapat $p=0,000$, maka terdapat pengaruh waktu fortifikasi vitamin $\mathrm{B}_{12}$ terhadap kandungan lemak pada kefir susu kambing. Dari hasil uji lanjut didapatkan perbedaan kandungan lemak antara kelompok kontrol dengan semua waktu fortifikasi, dan waktu fortifikasi jam ke 6 dengan waktu fortifikasi jam ke 18 .

Tabel 3. Analisis Lemak

\begin{tabular}{ll}
\hline Waktu Fortifikasi & $\begin{array}{l}\text { Rerata kandungan lemak } \\
(\mathbf{g r} / \mathbf{1 0 0 m})\end{array}$ \\
\hline Kontrol & $8,5 \pm 0,4^{\mathrm{ac}}$ \\
Jam ke 0 & $6,73 \pm 0,7^{\mathrm{bc}}$ \\
Jam ke 6 & $5,95 \pm 0,57^{\mathrm{b}}$ \\
Jam ke 12 & $6,13 \pm 0,77^{\mathrm{bc}}$ \\
Jam ke 18 & $6,43 \pm 0,083^{\mathrm{c}}$ \\
Jam ke 24 & $6,05 \pm 0,29^{\mathrm{bc}}$ \\
\hline \multicolumn{2}{c}{$p=0,000$} \\
\hline \multicolumn{2}{l}{ Keterangan : angka yang diikuti huruf super script berdeda $(\mathrm{a}, \mathrm{b}, \mathrm{c})$} \\
menunjukkan beda nyata
\end{tabular}


Vitamin $B_{12}$

Dari hasil analisis vitamin $\mathrm{B}_{12}$ pada kefir susu kambing fortifikasi vitamin B12 didapat $p=0,169$, maka tidak ada pengaruh waktu fortifikasi terhadap kandungan vitamin $\mathrm{B}_{12}$ yang terdapat pada kefir susu kambing.

Tabel 4. Analisis Vitamin $B_{12}$

\begin{tabular}{ll}
\hline Waktu Fortifikasi & $\begin{array}{l}\text { Rerata Konsentrasi Vitamin } \mathbf{B}_{\mathbf{1 2}} \\
(\boldsymbol{\mu g} / \mathbf{1 0 0} \mathbf{m l})\end{array}$ \\
\hline Kontrol & 767,5 \\
Jam ke 0 & 369,06 \\
Jam ke 6 & 590,31 \\
Jam ke 12 & 555,94 \\
Jam ke 18 & 524,37 \\
Jam ke 24 & 432,5 \\
\hline & $p=0,169$ \\
\hline
\end{tabular}

\section{Viskositas}

Hasil analisis viskositas pada kefir susu kambing dengan fortifikasi vitamin B12 didapat $p=0,007$, maka terdapat pengaruh waktu fortifikasi vitamin B12 terhadap viskositas pada kefir susu kambing. Dari hasil uji lanjut didapatkan perbedaan viskositas pada kefir susu kambing dengan fortifikasi vitamin $\mathrm{B}_{12}$.

Tabel 5. Analisis Viskositas

\begin{tabular}{ll}
\hline Waktu Fortifikasi & Rerata Viskositas $\mathbf{~ c m}^{2} / \mathbf{s} *$ \\
\hline Kontrol & $0,14^{\text {ae }}$ \\
Jam ke 0 & $0,09^{\mathrm{b}}$ \\
Jam ke 6 & $0,04^{\mathrm{c}}$ \\
Jam ke 12 & $0,07^{\mathrm{d}}$ \\
Jam ke 18 & $0,13^{\mathrm{e}}$ \\
Jam ke 24 & $0,03^{\mathrm{f}}$ \\
\hline & $p=0,007$ \\
\hline
\end{tabular}

*Data disajikan dalam Median; Keterangan : angka yang diikuti huru super script berdeda $(\mathrm{a}, \mathrm{b}, \mathrm{c}, \mathrm{d}, \mathrm{e}, \mathrm{f})$ menunjukkanbeda nyata

\section{Derajat Keasaman (pH)}

Hasil analisis $\mathrm{pH}$ pada kefir susu kambing dengan fortifikasi vitamin $\mathrm{B}_{12}$ didapat $p=0,045$, maka terdapat pengaruh waktu fortifikasi vitamin $\mathrm{B}_{12}$ terhadap $\mathrm{pH}$ pada kefir susu kambing. Dari hasil uji lanjut didapatkan perbedaan pHpada kefir susu kambing dengan fortifikasi vitamin $\mathrm{B}_{12}$.

Tabel 6. Analisis pH

\begin{tabular}{ll}
\hline Waktu Fortifikasi & Rerata $\mathbf{p H}^{*}$ \\
\hline Kontrol & $4,7^{\mathrm{ab}}$ \\
Jam ke 0 & $4,6^{\mathrm{a}}$ \\
Jam ke 6 & $4,6^{\mathrm{a}}$ \\
Jam ke 12 & $4,7^{\mathrm{ab}}$ \\
Jam ke 18 & $4,8^{\mathrm{b}}$ \\
Jam ke 24 & $4,7^{\mathrm{a}}$ \\
\hline & $p=0,045$ \\
\hline
\end{tabular}

*Data disajikan dalam Median; Keterangan : angka yang diikuti huruf super script berdeda $(\mathrm{a}, \mathrm{b})$ menunjukkan beda nyata
Total Bakteri Asam Laktat (BAL)

Hasil analisis total bakteri asam laktat pada kefir susu kambing yang telah difortifikasi vitamin B12 didapat $p=0,442$, maka tidak ada pengaruh waktu fortifikasi vitamin B12 terhadap total bakteri asam laktat pada kefir susu kambing.

Tabel 7. Analisis Total Bakteri Asam Laktat (x10 ${ }^{7}$ CFU/mL)

\begin{tabular}{ll}
\hline Waktu Fortifikasi & $\begin{array}{l}\text { Rerata Total BAL }\left(\mathbf{x 1 0}^{\mathbf{7}}\right. \\
\text { CFU/mL) }\end{array}$ \\
\hline Kontrol & $2,57 \pm 3,23$ \\
Jam ke 0 & $2,3 \pm 8,3$ \\
Jam ke 6 & $3,62 \pm 7,16$ \\
Jam ke 12 & $2,25 \pm 2,98$ \\
Jam ke 18 & $4,09 \pm 5,70$ \\
Jam ke 24 & $6,95 \pm 9,59$ \\
\hline & $p=0,442$ \\
\hline
\end{tabular}

\section{PEMBAHASAN}

\section{Protein}

Selama fermentasi akan terjadi hidrolisis protein oleh aktivitas enzim proteolitik yang memecah protein menjadi fraksi-fraksi protein yang lebih kecil. Selain itu juga proses fermentasi terjadi hidrolisis protein menjadi asam amino dan peptida oleh bakteri asam laktat dalam kefir grain yang bersifat proteolitik, terutama dari kelompok Lactobacillus. ${ }^{15,16}$ Asam amino bebas dan peptida digunakan oleh BAL sebagai sumber nutrisi untuk pertumbuhannya. Khamir yang ada dalam kefir mampu mendegradasi kasein menjadi komponenkomponen protein lebih sederhana berupa peptida dan asam asam amino bebas. ${ }^{17}$ Bibit kefir yang digunakan pada pembuatan kefir juga mempengaruhi kandungan protein pada kefir. Pada penelitian ini jumlah bibit kefir yang ditambahkan sama pada kelompok kontrol maupun perlakuan, sehingga tidak terjadi perbedaan kandungan protein pada produk akhir kefir. Kandungan protein pada kefir susu kambing yang difortifikasi vitamin $\mathrm{B}_{12}$ setelah difermentasi selama 24 jam yaitu 0,69 $\mathrm{gr} / 100 \mathrm{ml}$.

\section{Serat}

Laktosa di dalam kefir dihidrolisis, kemudian galaktosa yang dihasilkan dari hasil hidrolisa digunakan untuk membentuk polimer kefiran. Hasil dari penelitian ini diketahui bahwa kandungan serat pada kefir lebih rendah dibandingkan dengan kelompok kontrol. Produksi kefiran dapat dipengaruhi oleh suhu, sumber karbon, vitamin dan mineral yang ada didalam kultur. ${ }^{18}$ Penambahan vitamin $\mathrm{B}_{12}$ pada waktu fortifikasi jam ke $0,6,12$, 18 dan 24 digunakan bakteri atau khamir untuk berkembangbiak. Waktu fortifikasi jam ke 12 produksi khamir mencapai puncak sehingga terjadi 
peningkatan kandungan serat. Peningkatan jumlah khamir akan berpengaruh terhadap produksi exopolysaccaharide pada kefir. Waktu fortifikasi jam ke 18 bakteri mencapai puncaknya tetapi kadar serat mengalami penurunan, hal ini karena produksi khamir yang berlebihan akan menghambat biosintesis exopolysaccaharide, yang mengakibatkan khamir akan mengkonsumsi lebih banyak laktosa, sehingga lebih sedikit laktosa yang dikonsumsi oleh bakteri untuk membentukan exopolysaccaharide. ${ }^{19,20}$

\section{Lemak}

Hasil uji kandungan lemak pada kefir susu kambing yang difortifikasi vitamin $\mathrm{B}_{12}$ pada seluruh kelompok perlakuan lebih rendah dari peda kelompok kontrol. Proses fermentasi dapat memecah lemak pada kefir susu kambing. Penambahan vitamin $B_{12}$ pada kefir susu kambing menyebabkan peningkatan perkembangbiakan bakteri asam laktat. ${ }^{21}$ Perkembangbiakan BAL dalam proses fermentasi akan menyebabkan enzim lipase yang dihasilkan semakin banyak sehigga lemak yang terhidrolisis juga semakin banyak, mengakibatkan turunnya kadar lemak.

Susu yang memiliki kandungan padatan total (total solid) tinggi diduga mempunyai keasaman yang lebih tinggi dari pada kondisi standar. Secara umum penurunan keasaman menandakan kecenderungan mengarah pada penurunan persentase lemak, padatan total, padatan non lemak, kasein, dan laktat. Dalam penelitian ini susu kambing memiliki total padatan yang tinggi, sehingga terjadi kecenderungan pada penurunan persentasi lemak ada kefir susu kambing.

\section{Vitamin $B_{12}$}

Penambahan vitamin $\mathrm{B}_{12}$ selama proses fermentasi dapat meningkatkan akumulasi produksi asam propionat yang dapat menghambat pertumbuhan sel bakteri yang menyebabkan turunnya kandungan vitamin $\mathrm{B}_{12}$. Asam propionat adalah produk sampingan dari vitamin $\mathrm{B}_{12}$ yang dihasilkan dari Propionibacterium freudenreichii. ${ }^{21}$ Hasil penelitian ini menunjukkan rendahnya kandungan vitamin $B_{12}$ yang telah difortifikasi dibandingkan dengan kontrol. Hal ini dikarenakan penambahan vitamin $\mathrm{B}_{12}$ meningkatkan akumulasi asam propionic sehingga dapat menghambat pertumbuhan sel bakteri yang akan menyebabkan penurunan produksi vitamin B12. Pada waktu fortifikasi jam ke 0 kandungan $B_{12}$ lebih rendah dibandingkan waktu fortifikasi pada kelompok lain karena penambahan vitamin $\mathrm{B}_{12}$ pada jam ke 0 akan menghasilkan asam propionat lebih banyak sehingga menghambat pertumbuhan sel bakteri. Waktu fortifikasi jam ke-24 mengalami penurunan kandungan vitamin $B_{12}$, hal ini terjadi karena setelah dilakukan pemisahan bibit dengan kefir terjadi waktu tunggu sehingga pertumbuhan bateri tetap berjalan dan menyebabkan kandungan vitamin $B_{12}$ menurun.

\section{Viskositas}

Penelitian ini menunjukkan adanya penurunan viskositas selama proses fermentasi jam ke 0,6 , dan 24 , hal ini berkaitan dengan sedikitnya produksi exopolysaccharide yang dihasilkan oleh bakteri asam laktat.Bakteri asam laktat diproduksi pada fermentasi jam ke 12 dan $18 .{ }^{22}$ Penambahan vitamin $\mathrm{B}_{12}$ pada waktu fortifikasi jam ke 12 dan 18 dapat meningkatkan viskositas pada kefir susu kambing, hal ini dikarenakan pertumbuhan bakteri asam laktat mencapai pada titik maksimum. Vitamin $B_{12}$ yang ditambahkan pada kefir susu kambing dapat memicu perkembangbiakan bakteri asam laktat. Jumlah bakteri asam laktat yang meningkat akan menhasilkan texturising agents eksoselular exopolysaccharide dan berinteraksi dengan protein susu sehingga meningkatkan viskositas pada kefir susu kambing. ${ }^{21,23,24}$

Produksi exopolysaccharide dipengaruhi oleh suhu, $\mathrm{pH}$ dan jumlah ragi. ${ }^{20}$ Selain itu juga viskositas pada kefir dipengaruhi oleh psikologi ternak seperti pakan, bangsa ternak dan lingkungan. viskositas pada kefir tidak terlepas dari terjadi agregasi kasein susu sewaktu mengalami pemanasan. ${ }^{25}$ Hasil penelitian menunjukkan bahwa pemanasan susu berpengaruh terhadap viskositas yang disebabkan oleh adanya ikatan antara kasein dan $\beta$-laktoglobulin melalui ikatan disulfida, begitu juga laktalbumin akan bereaksi dengan $\beta$-laktoglobulin. ${ }^{26}$

\section{Derajat keasaman (pH)}

Nilai pH pada penelitian ini berkisar 4,6 -4,8. Sebuah penelitian ada yang menyatakan bahwa $\mathrm{pH}$ pada kefir yaitu 4,85 pada akhir fermentasi. ${ }^{22}$ Penurunan $\mathrm{pH}$ terjadi karena adanya aktivitas BAL dalam menghasilkan energi melalui proses fermentasi dengan memecah substrat menjadi komponen yang lebih sederhana. Pembentukan energi ditunjukkan untuk pembentukan sel. Selain dihasilkan energi pemecahan laktosa juga menghasilkan asam laktat, pembentukan asam tersebut yang kemudian terakumulasi menyebabkan turunnya nilai $\mathrm{pH} .{ }^{27,28}$

Pertumbuhan bakteri asam laktat meningkat pada waktu fortifikasi jam ke 12 dan 18, sehingga penambahan vitamin $\mathrm{B}_{12}$ mempengaruhi pertumbuhan bakteri asam laktat yang mengakibatkan nilai $\mathrm{pH}(4,7-4,8)$ pada waktu fortifikasi jam tersebut berbeda dengan waktu fortifikasi jam ke 0,6,24, karena pada jam tersebut pertumbuhan bakteri asam laktat belum maksimal. 


\section{Total Bakteri Asam Laktat (BAL)}

Jenis bakteri asam laktat yang terkandung dalam kefir yaitu, Lactobacillus fermentum, Lactobacillus acidhophilus, Lactobacillus helveticus, Lactobacillus casei, Lactobcillus kefiri, Leuuconostoc mesenteroides, Lactobacillus parakefiri, Lactobacillus brevis, dan Lactococus lactic. Pertumbuhan Lacidophilus pada kefir susu kambing yang lambat didukung oleh waktu inkubasi kefir yang lama (24 jam) menyebabkan jumlah bakteri pada produk akhir tidak menunjukkan hasil yang signifikan. Beberapa faktor yang mempengaruhi jumlah L.acidophilus antara lain kepadatan starter saat inokulasi, suhu inkubasi dan karakteristik dari bakteri asam laktat itu sendiri. ${ }^{29,30}$ Hasil penelitian yang telah dilakuakn pengujian total bakteri asam laktat yang terdapat pada kefir susu kambing dengan fortifikasi vitamin B12 menunjukkan bahwa jumlah bakteri asam laktat memenuhi standar codex yaitu minimal $7 \log 10$ Cfu mL. ${ }^{31}$

\section{SIMPULAN}

Waktu fortifikasi Vitamin $\mathrm{B}_{12}$ pada kefir susu kambing tidak berpengaruh pada kandungan vitamin $\mathrm{B}_{12}$, protein, dan total $\mathrm{BAL}$, tetapi terdapat pengaruh pada kandungan serat, lemak, viskositas, dan $\mathrm{pH}$. Produk kefir susu kambing fortifikasi vitamin $\mathrm{B}_{12}$ terbaik adalah pada waktu fortifikasi jam ke-6 yang memiliki kandungan vitamin $\mathrm{B}_{12}$ sebanyak 590,31 $\mu \mathrm{g} / 100 \mathrm{ml}$ kefir susu kambing. Kandungan serat, lemak, viskositas, pada perlakuan yang diberi fortifikasi lebih rendah dibandingkan dengan kontrol, sedangkan kandungan protein memiliki kandungan yang lebih tinggi dibandingkan kontrol. Nilai $\mathrm{pH}$ pada kefir fortifikasi vitamin $\mathrm{B}_{12}$ bekisar 4,6-4,7 dan total bakteri asam laktat pada penelitian ini sudah memenuhi standar Codex yaitu $\geq 10^{7}$ $\mathrm{CFU} / \mathrm{ml}$. Perlu dilakukan penelitian lanjutan untuk mempertahankan kandungan fortifikan pada bahan pangan (Vitamin B-12) dengan teknik tertentu seperti enkapsulasi.

\section{UCAPAN TERIMA KASIH}

Penulis mengucapkan terimakasih kepada Riset Pengembangan dan Penerapan PNBP Fakultas Kedokteran Universitas Diponegoro tahun anggaran 2016 atas didanainya penelitian ini.

\section{DAFTAR PUSTAKA}

1. Mukherjee B, Hossain CM, Mondal L, Paul P, Ghosh MK. Obesity and insulin resistance: an abridged molecular correlation. Lipid Insight. 2013; 6: 1-11.

2. Trial DPC, Ostadrahimi A, Taghizadeh A, Mobasseri M. Effect of probiotic fermented milk ( kefir ) on glycemic control and lipid profile in type 2 diabetic patients: a randomized doble-blind placebo-controlled clinical trial. Iran J Public Health. 2015;44(2):228-37.

3. Satir G, Guzel-Seydim ZB. Influence of kefir fermentation on the bioactive substances ofdifferent breed goat milks. LWT - Food Sci Technol. 2015;63(2):852-8.

4. Ribeiro AC, Ribeiro SDA. Specialty products made from goat milk. Small Ruminant Research. 2010; 89(2):225-33.

5. Kumar S, Kumar B, Kumar R, Kumar S, Khatkar SK and Kanawjia SK. Nutritional Features of Goat Milk-A Review. Indian J Diary Sci. 2012; 65(4): 266-273.

6. Haenlein GFW. Goat milk in human nutrition. 2004;51:155-63.

7. Ahmed T, Haque R, Ahmed AMS, Petri WA, Cravioto A. Use of metagenomics to understand the genetic basis of malnutrition. Nutr Rev. 2009;67(SUPPL. 2):201-6.

8. Teruya K, Yamashita M, Tominaga R, Nagira T, Shim SY, Katakura Y, et al. Fermented milk, Kefram-Kefir enhances glucose uptake into insulin-responsive muscle cells. Cytotechnology. 2002;40(1-3):107-16.

9. Nurliyani, Harmayani E, Sunarti. Antidiabetic potential of kefir combination from goat milk and soy milk in rats induced with streptozotocin-nicotinamide. Korean J Food Sci Anim Resour. 2015;35(6):847-58.

10. Ayustaningwarno F dkk. Ilmu dan Teknologi Pangan. 1st ed. Semarang: UPT UNDIP Press Semarang; 2013. 378 p.

11. Pop C, Apostu S, Salanţă L, Rotar AM, Sindic $\mathrm{M}$, Mabon $\mathrm{N}$, et al. Influence of different growth conditions on the kefir grains production, used in the kefiran synthesis. Bull UASVM Food Sci Technol. 2014;71(2).

12. Al-Maskari MY, Waly MI, Ali A, Al-Shuaibi YS, Quhtit A. Folate and vitamin B12 de fi ciency and hyperhomocysteinemia promote oxidative stress in adult type 2 diabetes. Nutrition. 2012;28(7-8):e23-6.

13. Ho M, Halim JH, Gow ML, El-haddad N, Marzulli T, Baur LA, et al. Vitamin B12 in obese adolescents with clinical features of insulin resistance. Nutrients. 2014;6(12):56118.

14. Baltaci D, Kutlucan A, Turker Y, Yilmaz A, Karacam S, Deler $\mathrm{H}$, et al. Association of vitamin B12 with obesity, overweight, insulin resistance and metabolic syndrome, and body fat composition; primary care-based study. Medicinski Glasnik. 2013; 10(2): 203-10. 
15. Belkaaloul K, Chekroun A, Ait-Abdessalam A, Saidi D, Kheroua O. Growth, acidification and proteolysis performance of two co-cultures (Lactobacillus plantarum-Bifidobacterium longum and Streptococcus thermophilusBifidobacterium longum). African J Biotechnol. 2010;9(10):1463-9.

16. Kabadjova-Hristova P, Bakalova S, Gocheva B, Moncheva P. Evidence for proteolytic activity of lactobacilli isolated from kefir grains. Biotechnol Biotechnol Equip. 2006;20(2):8994.

17. Kahala M, Pahkala E, Pihlanto-Leppala A. Peptides in fermented Finnish milk products. Agric Sci Finl. 1993;2(5):379-86.

18. Zajšsek K, Goršek A, Kolar M. Cultivating conditions effects on kefiran production by the mixed culture of lactic acid bacteria imbedded within kefir grains. Food Chem. 2013;139(14):970-7.

19. Irigoyen A, Arana I, Castiella M, Torre P, Ibáñez FC. Microbiological, physicochemical, and sensory characteristics of kefir during storage. Food Chem. 2005;90(4):613-20.

20. Gorret N, Maubois JL, Engasser JM, Ghoul M. Study of the effects of temperature, $\mathrm{pH}$ and yeast extract on growth and exopolysaccharides production by Propionibacterium acidipropionici on milk microfiltrate using a response surface methodology. J Appl Microbiol. 2001;90(5):788-96.

21. Watanabe F. Vitamin B12 sources and bioavailability. Exp Biol Med. 2007;232(10):1266-74.

22. Leite AMO, Leite DCA, Del Aguila EM, Alvares TS, Peixoto RS, Miguel MAL, et al.
Microbiological and chemical characteristics of Brazilian kefir during fermentation and storage processes. J Dairy Sci. 2013;96(7):4149-59.

23. Farnworth ER. Kefir - A complex probiotic. Food Sci Technol Bull Funct Foods. 2005;2(1):1-17.

24. Beshkova DM, Simova ED, Simov ZI, Frengova GI, Spasov ZN. Pure cultures for making kefir. Food Microbiol. 2002;19(5):53744.

25. Liu JR, Lin CW. Production of kefir from soymilk with or without added glucose, lactose, or sucrose. J Food Sci. 2000;65(4):716-9.

26. Trachoo N. Yogurt: The fermented milk. J Sci Technol. 2002;24(4)(February):727-37.

27. Adesokana I., Odetoyinbo B., Ekanola Y., Avanrenren R., Fakorede S. Production of Nigerian Nono Lacric Starter Cultures. Pakistan Journal of Nutrition. 2011;10(3): 203-7.

28. Kunci K, Asam Laktat B. Effect of lactic acid bacteria starter use of lactobacillus plantarum and lactobacillus fermentum terhadaptotal bacteria lactic acid, acid content and $\mathrm{pH}$ value of curd Milk Cow. J Ilm Ilmu-Ilmu Peternak Mei. 2010;XIII(6):279-85.

29. Safitri MF, Swarastuti A. Kualitas kefir berdasarkan konsentrasi kefir grain. J Apl Teknol Pangan. 2013;2(2):87-92.

30. Aristya AL, Legowo AM, Al-baarri AN. Karakteristik fisik, kimia, dan mikrobiologis kefir susu kambing dengan penambahan jenis dan konsentrasi gula yang berbeda. Apl Teknol Pangan. 2013;2(3):139-43.

31. Commission CA. Codex Alimentarius. FAO/WHO Food Standards; 2003. 